DOI : 10.33451/florafauna.v26i1pp29-36

FLORA AND FAUNA

ISSN 2456 - 9364 (Online)

2020 Vol. 26 No. 1 PP 29-36

ISSN 0971 - 6920 (Print)

\title{
Navisporus floccosus causing heart rot in tropical trees
}

${ }^{*}$ R.K. Verma ${ }^{1}$, Vimal Pandro ${ }^{2}$ and Poonam Verma ${ }^{3}$

\author{
${ }^{1}$ Forest Pathology Discipline, Forest Protection Division, \\ ${ }^{2}$ Genetics and Tree Improvement Division, \\ Tropical Forest Research Institute, \\ JABALPUR - 482 021, M.P., INDIA \\ ${ }^{3}$ BioDesign Innovation Centre, \\ Rani Durgavati University, \\ JABALPUR, 482001, MP, INDIA \\ *Corresponding Author \\ E-mail: rkverma28@rediffmail.com
}

Received : 18.02.2020; Accepted : 12.04.2020

\begin{tabular}{|c|c|c|}
\hline $\begin{array}{l}\text { Navispo } \\
\text { innata and Sh } \\
\text { pecies of the }\end{array}$ & $\begin{array}{l}\text { ABSTRACT } \\
\text { ical trees (Dalb } \\
\text { jarh, Madhya Pr }\end{array}$ & $\begin{array}{l}\text { is, Ponga } \\
\text { of eight ot }\end{array}$ \\
\hline Figures : 17 & References : 17 & Tables : 02 \\
\hline
\end{tabular}

\section{Introduction}

Eight species of tropical poroid fungus genus, Navisporus (family Polyporaceae) are known. The genus was established by Leif Ryvarden with Navisporus floccosus as the type species. Earlier it was reported as Trametes floccosa ${ }^{3}$ and was thought to have been originally collected in Tanzania ${ }^{12}$. Species of this genus have pale brown context and a dimitic hyphal system, meaning they have both generative and skeletal hyphae. The genus is very close to Pseudopiptoporus simultaneously with Navisporus, but with dextrinoid skeletal hyphae, lacking gloeopleurous hyphae. Navisporus spores are long, boat-shaped (navicular) and non-dextrinoid ${ }^{16}$. N. terrestris is the only species in the genus that has a fruit body with a stipe and also the only member of the genus that fruits on soil. All of the other species fruit as a stipeless (sessile) cap on dead wood, or alternately in effused-reflexed form i.e. a crust fungus with margins which form caps ${ }^{6}$. Another root-rot disease of Dalbergia sissoo caused by Amauroderma niger has been studied and reported. The pathogen has been described as a new record for India along with cultural characters. The pathogenicity has been established through artificial inoculation. The disease spreads from tree to tree through root contact ${ }^{8}$. Navisporus floccosus also causing heart rot in Alianthus excelsa, the fungus decayed mostly heartwood of living tree and colonized the central portion of stem which begins decaying of wood and ultimately lead to death of infected tree ${ }^{10}$.

In the present article Navisporus floccosus causing heart rot in tropical trees of Chhattisgarh, Madhya Pradesh and Odisha is reported alongwith a report on worldwide distribution of eight other species of the genus.

\section{Materials and Methods}

\section{Study sites}

Specimens were collected from Chhattisgarh, Madhya Pradesh and Odisha. Five specimens were collected from Chhattisgarh and Madhya Pradesh, these include on stems of Pongamia pinnata and Dalbergia sissoo from Jabalpur, Madhya Pradesh; on Ficus bengalensis and Dalbergia latifolia from Gariabandh, Ballod, Bhilai Nagar and on Shorea robusta from Kondagao (Chhattisgarh). One specimen was collected on Ficus bengalensis from Natavega (Odisha).

\section{Collection of samples}

Samples were collected in paper bags; sun dried and brought to laboratory for study. A portion of fresh 
TABLE-1: Distribution of Navisporus floccosus on different tree species in central India

\begin{tabular}{l|c|c|c|c}
\hline S.N. & $\begin{array}{c}\text { Date of } \\
\text { collection }\end{array}$ & $\begin{array}{c}\text { Accession } \\
\text { Number }\end{array}$ & Host & Locality \\
\hline 1. & $07 / 07 / 1987$ & TF 990 & Pongamia pinnata & Jabalpur, Madhya Pradesh \\
\hline 2. & $01 / 10 / 2008$ & TF 1787 & Ficus bengalensis & Gariabandh, Chhattisgarh \\
\hline 3. & $3 / 10 / 2008$ & TF 1909 & Shorea robusta & Kondagao, Chhattisgarh \\
\hline 4. & $11 / 9 / 2009$ & TF 2434 & Ficus bengalensis & Natavega, Bhanjnagar, Odisha \\
\hline 5. & $19 / 08 / 2011$ & TF 3122 & Ficus bengalensis & Ballod, Durg, Chhattisgarh \\
\hline 6. & $21 / 10 / 2016$ & TF 3851 & Dalbergia sissoo & Jabalpur, Madhya Pradesh \\
\hline 7. & $04 / 2 / 2017$ & TF 4063 & Dalbergia sissoo & Bhilai Nagar, Durg, Chhattisgarh \\
\hline 8. & $05 / 2 / 2017$ & TF 4065 & Dalbergia latifolia & Rajhara, Balod, Chhattisgarh \\
\hline
\end{tabular}
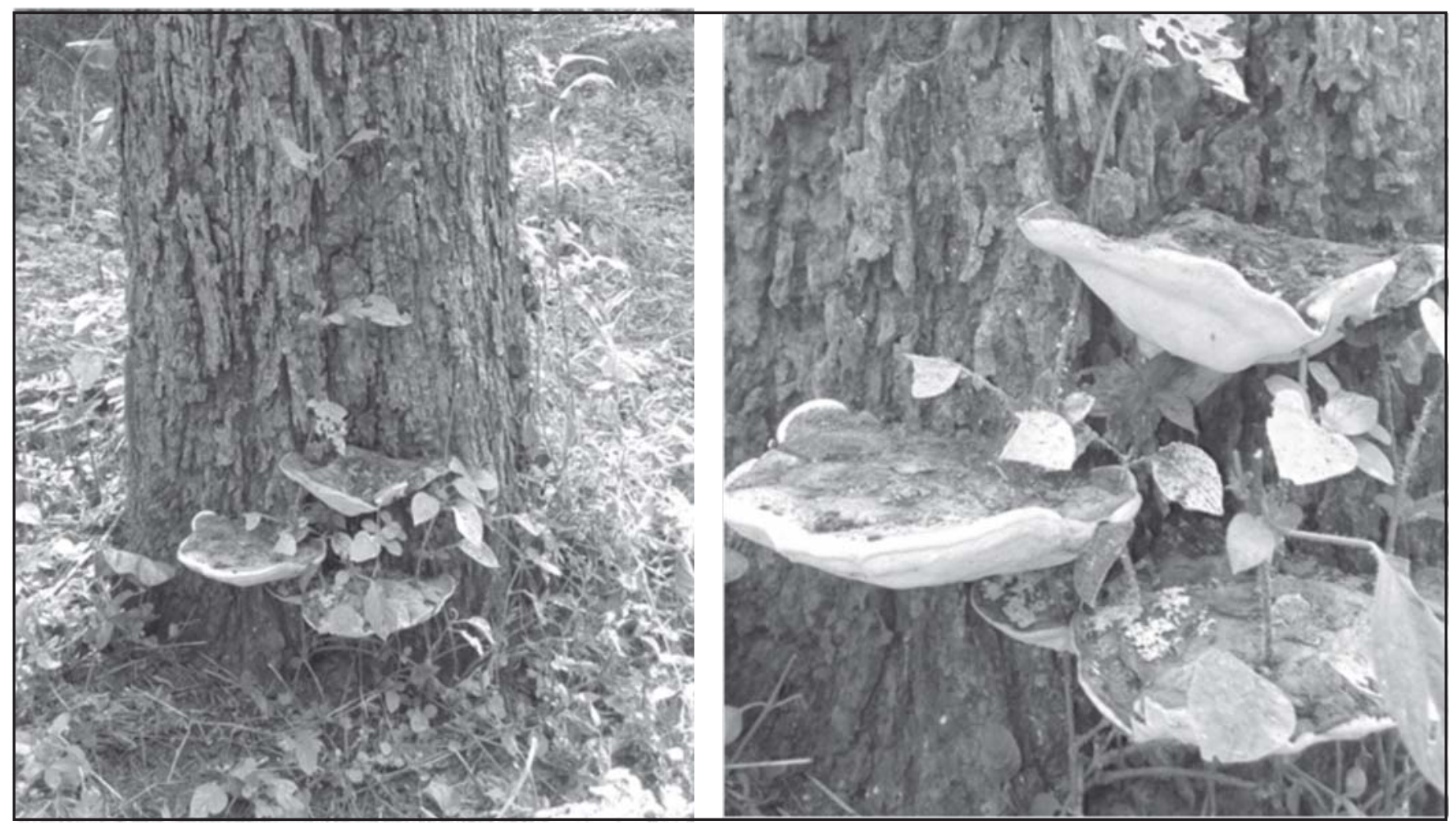

Figs. 1-2 : Navisporus floccossus on dead tree of Dalbergia sissoo: fruit bodies attached to main stem in habit (TF 3851) 

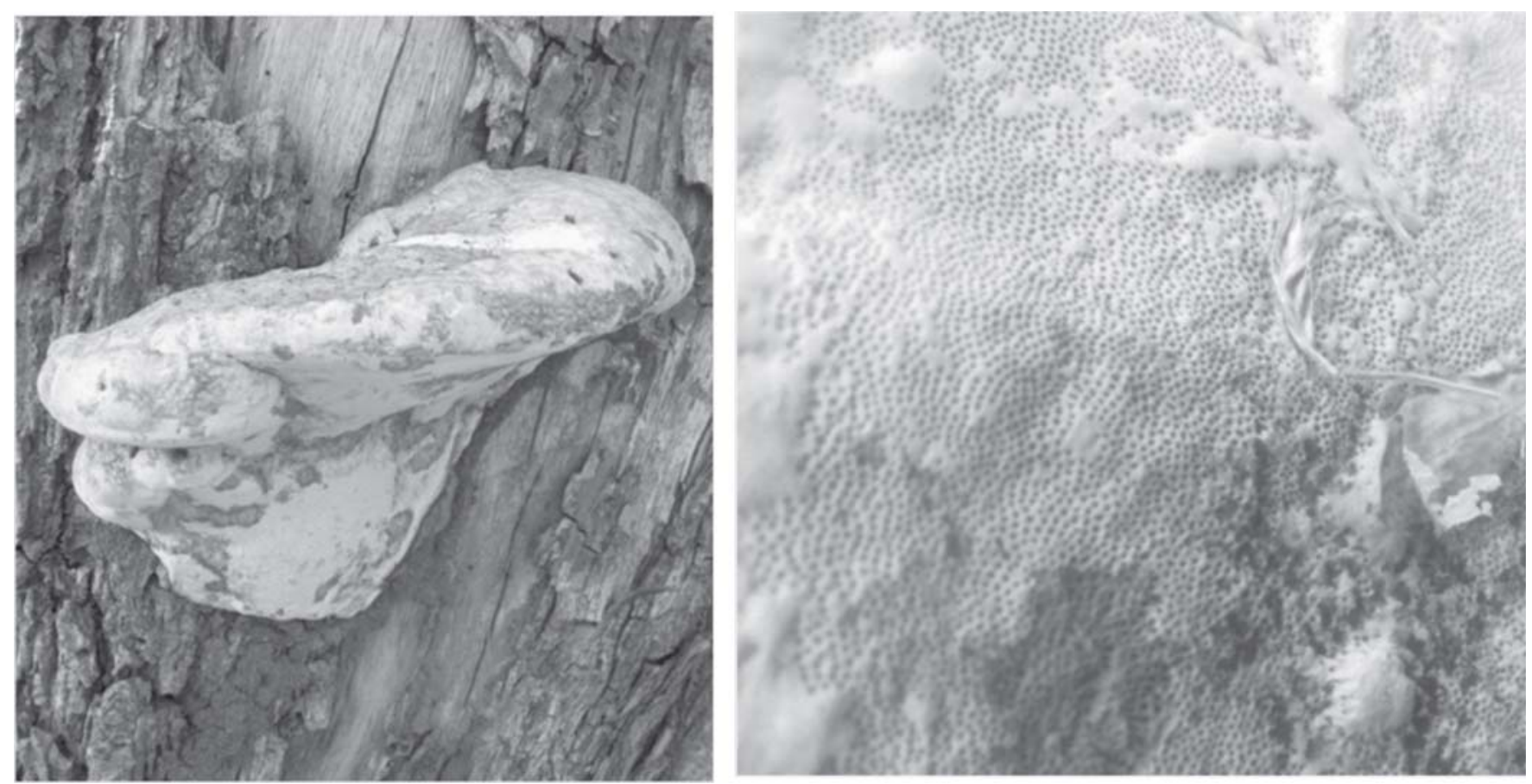

Figs. 3-4 : Navisporus floccossus on Dalbergia sissoo: fruit bodies attached to main stem in habit and details of pore surface (TF 4063)
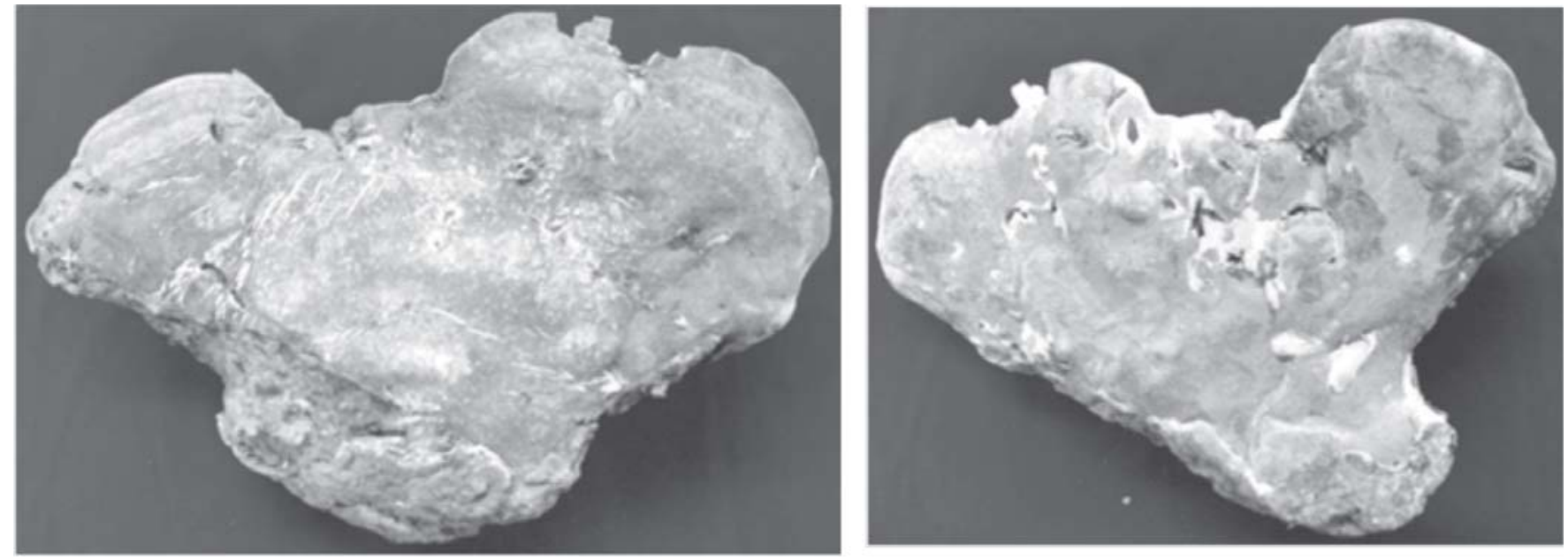

Figs. 5-6 Navisporus floccossus on Ficus bengalensis, Gariabandh, CG (TF 1787)

specimen was preserved in $70 \%$ alcohol in the field just after the collection for preparation of microscopic slides.

\section{Identification of fungi}

The slides were prepared in lactophenol and cotton blue and observed under advance Research Microscope, make Leica, Germany and photomicrographs were taken with a digital camera attached to the microscope. Identification of fungi was done with the help of literature ${ }^{1-3,6,7,10-12,16}$. The specimens were deposited in the Mycology Herbarium, Tropical Forest Research Institute, Jabalpur and got accession numbers.

\section{Results}

Navisporus floccosus (Bres.) Ryvarden (Figures 1-17)
=Fomes introstuppeus Henn. Bot. Jb. 14: 343 (1891) [1892]

=Ganoderma mollicarnosum (Lloyd) Sacc. \& Trotter [as 'molli-carnosum'], Syll. fung. (Abellini) 23: 401 (1925)

=Polyporus mollicarnosus Lloyd Mycol. Writ. 4 (Letter 60): 11 (1915)

=Trametes floccosa Bres. Annuar. R. Ist. bot. Roma 6: 179 (1896)

=Tyromyces floccosus (Bres.) A. Roy \& A.B. De (as 'floccosa') Norw. Jl Bot. 27(4): 300 (1980)

\section{Taxonomic Description:}

Basidiome: annual, solitary, soft and fleshy when young coriaceous and punky when dry, sessile, pileate, 

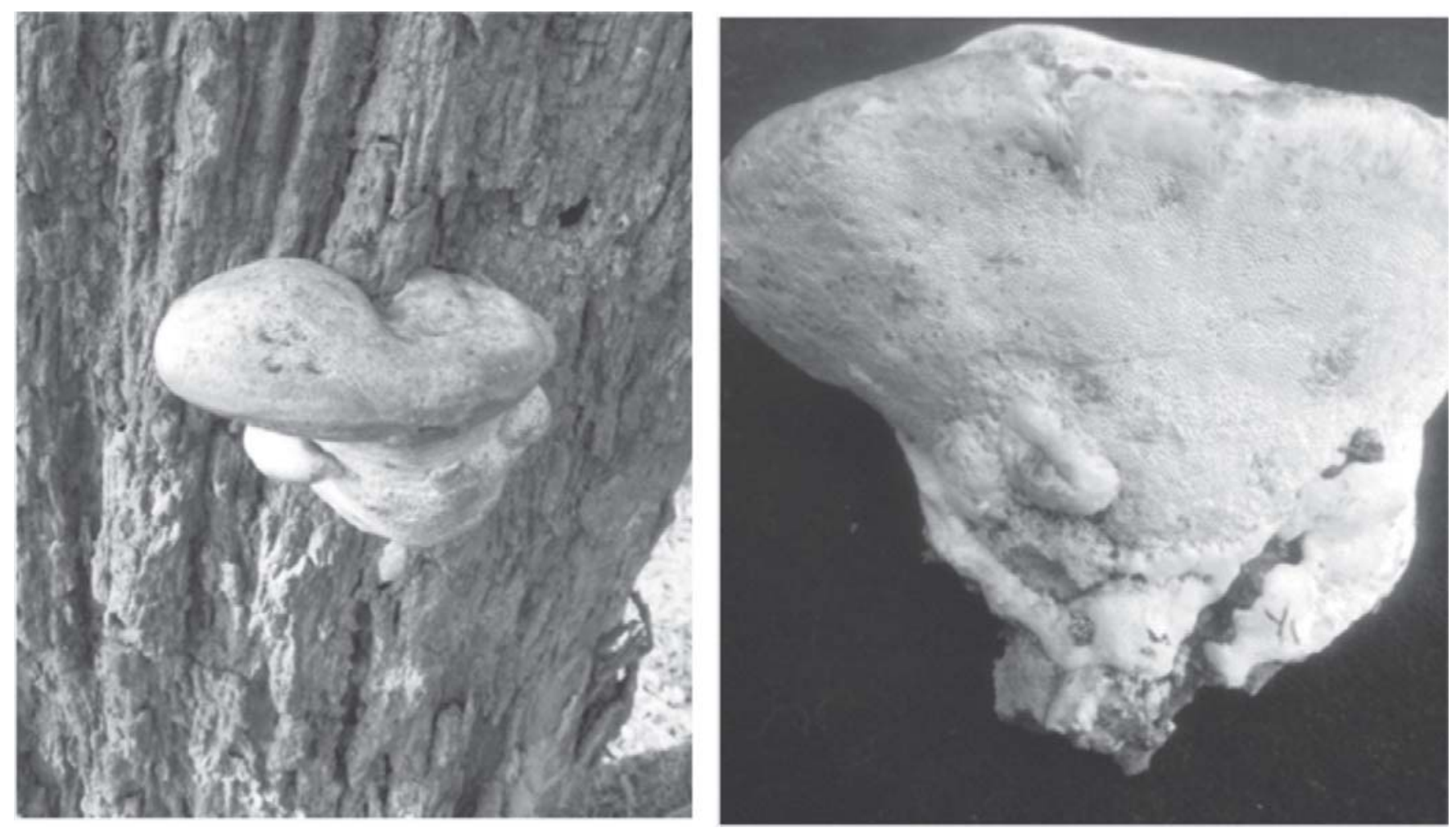

Figs. 7-8 Navisporus floccossus on Dalbergia latifolia: fruit body in habit and pore surface (TF 4063)
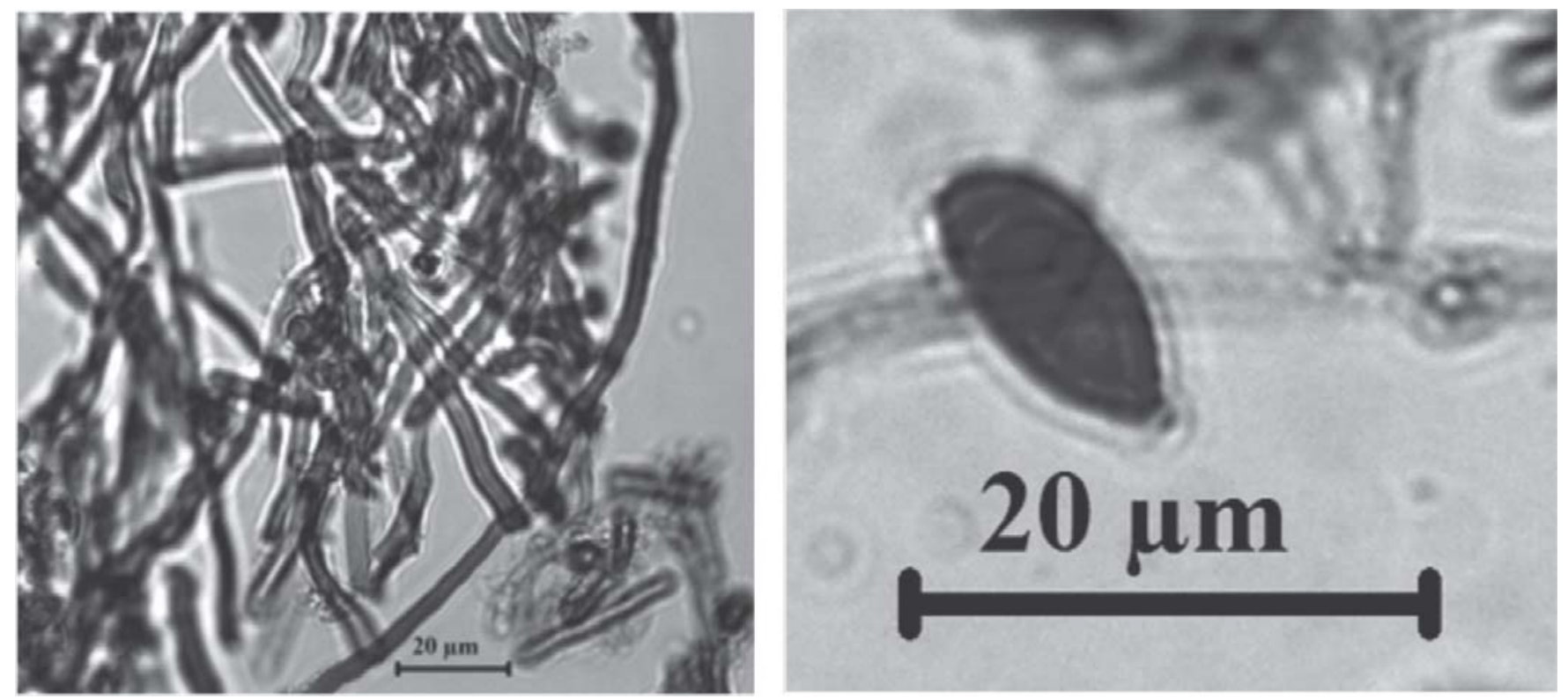

Figs. 9-10 Navisporus floccossus on Ficus bengalensis: 1-2 Upper and hymenium surfaces of fruit body, 3 generative hyphae and 4 basidiospore

dimidiate, applanate, $390 \times 200 \times 180 \mathrm{~mm}, 20-50 \mathrm{~mm}$ from the margin. Pileus ochraceous to brown when young changing dark brown with the age, soft and spongy, scrupose towards base, azonate. Context: light to sepia brown. Hymenium: cream to ochraceous, pores round to angular 2-3/mm. Hyphal system: monomitic, generative hyphae hyaline thin walled, clamped, up to $6.0 \mu \mathrm{m}$ wide.
Basidia: clavate. Basidiospores: boat shape, hyaline, thinwalled, 9.0-12.0x 4.0-5.5 $\mu \mathrm{m}$. The fungus is causing white fibrous rot in wood.

Specimens examined: On stem of Pongamia pinnata, Jabalpur, Madhya Pradesh; on Ficus bengalensis, Gariabandh and Ballod, Durg; on Shorea robusta Kondagoao, Chhattisgarh, on Ficus bengalensis 

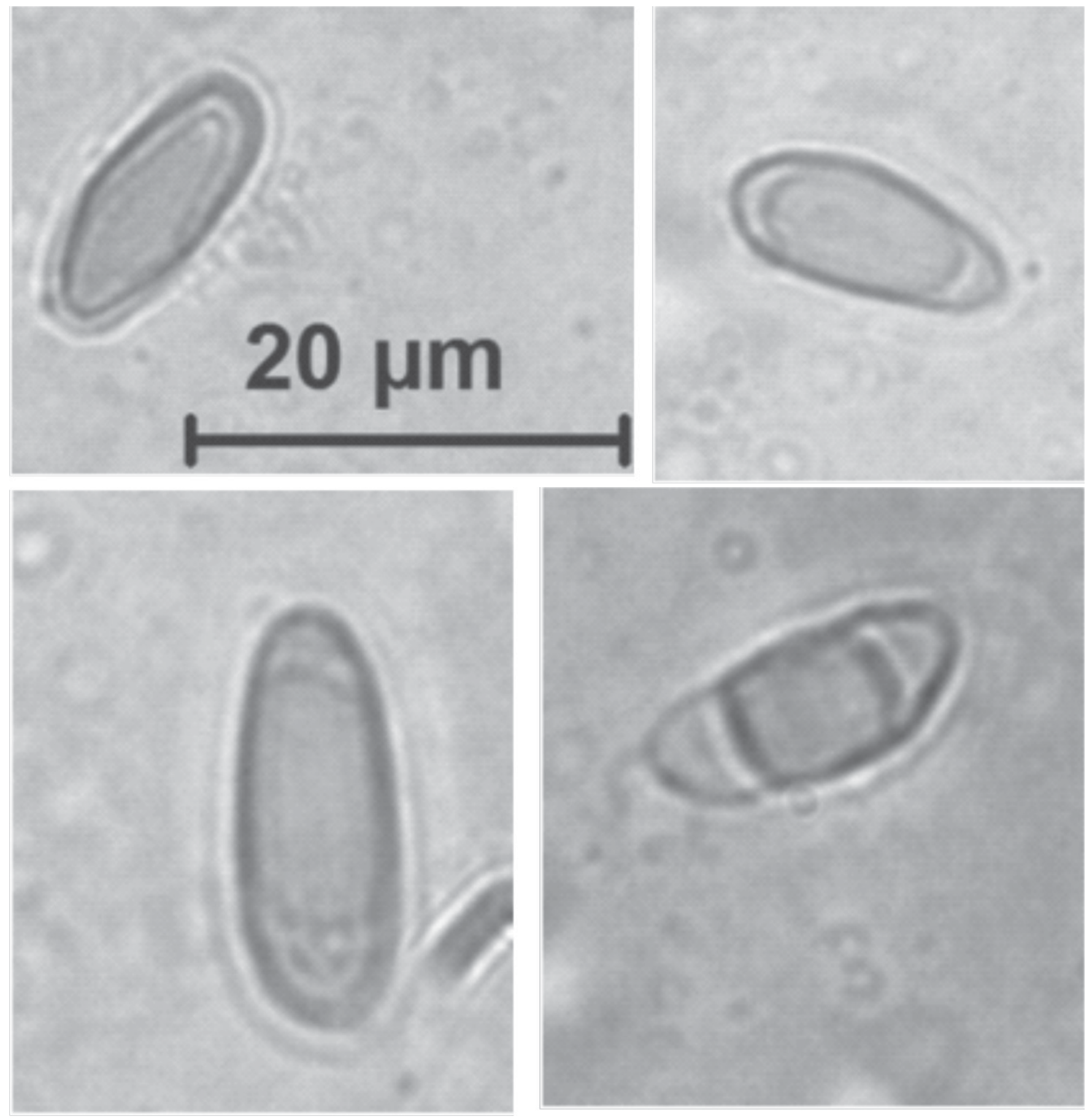

Figs. 11-14 Navisporus floccossus on Dalbergia sissoo: boat shaped basidiospores in different views (TF 3851)

Natavega, Odisha, on Dalbergia sissoo Jabalpur, Madhya Pradesh and Bhilai Nagar, Durg; on Dalbergia latifolia, Rajhara, Balod, Chhattisgarh; Mycology Herbarium, Tropical Forest Research Institute, TF 990, 1787, 1909, 2434, 3122, 3851, 4063 and 4065.

Details of specimens collected and studied in the present study are presented in Table 1.

Eight species of Navisporus including Navisporus floccosus are reported from the World (Table 2). In India it was reported from Darjeeling, Calcutta, West Bengal and Andhra Pradesh ${ }^{5,6,9,11}$. From central India it is reported from Chhattisgarh and Odisha ${ }^{17}$. From Madhya Pradesh is being reported for the first time on Pongamia pinnata and Dalbergia sissoo in this article.

\section{Discussion}

Eight species under genus Navisporus are known which are reported from different regions of the world. Navisporus africanus was reported on dead hardwoods 


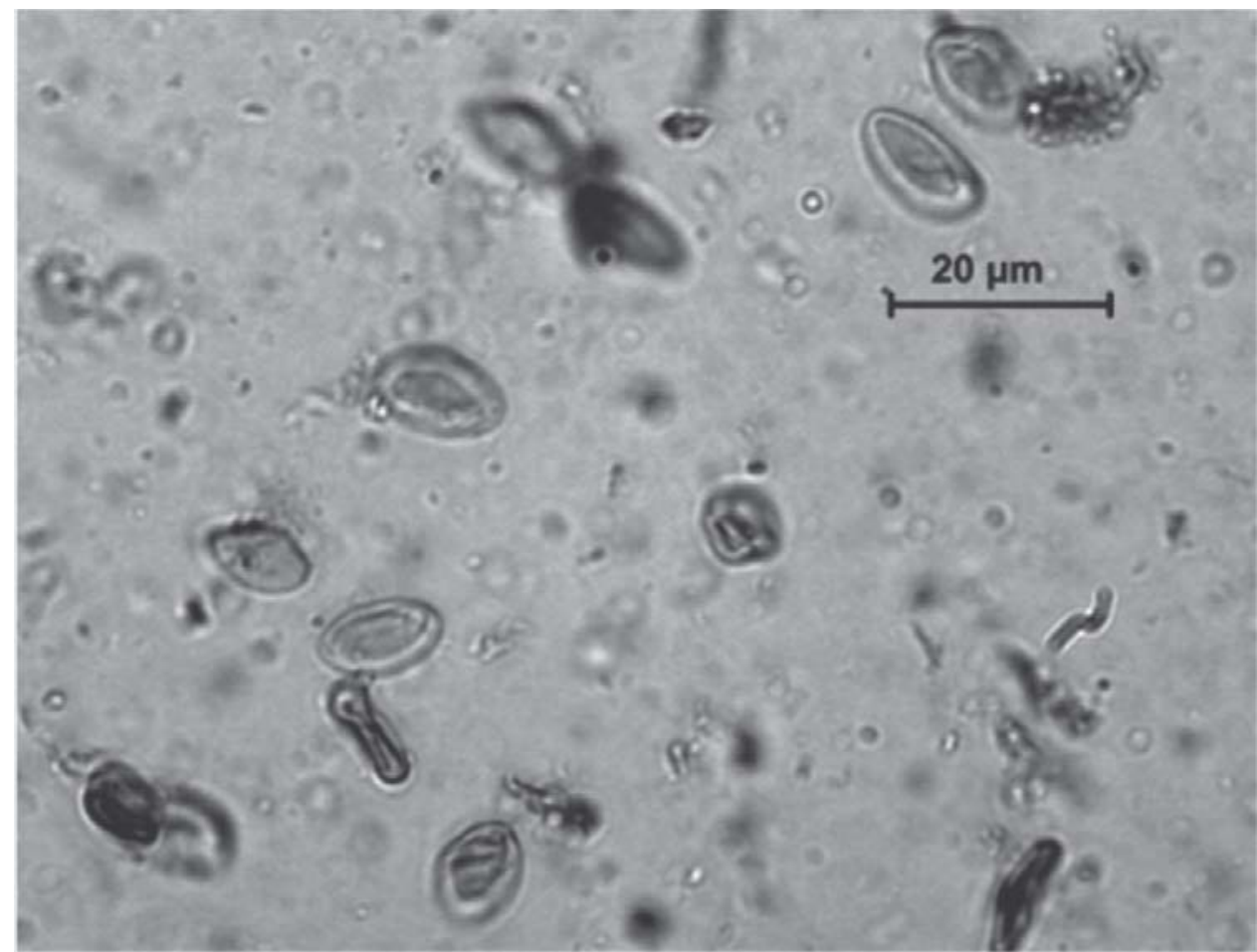

Fig. 15 : Navisporus floccossus on Pongamia pinnata: boat shaped basidiospores (TF990)

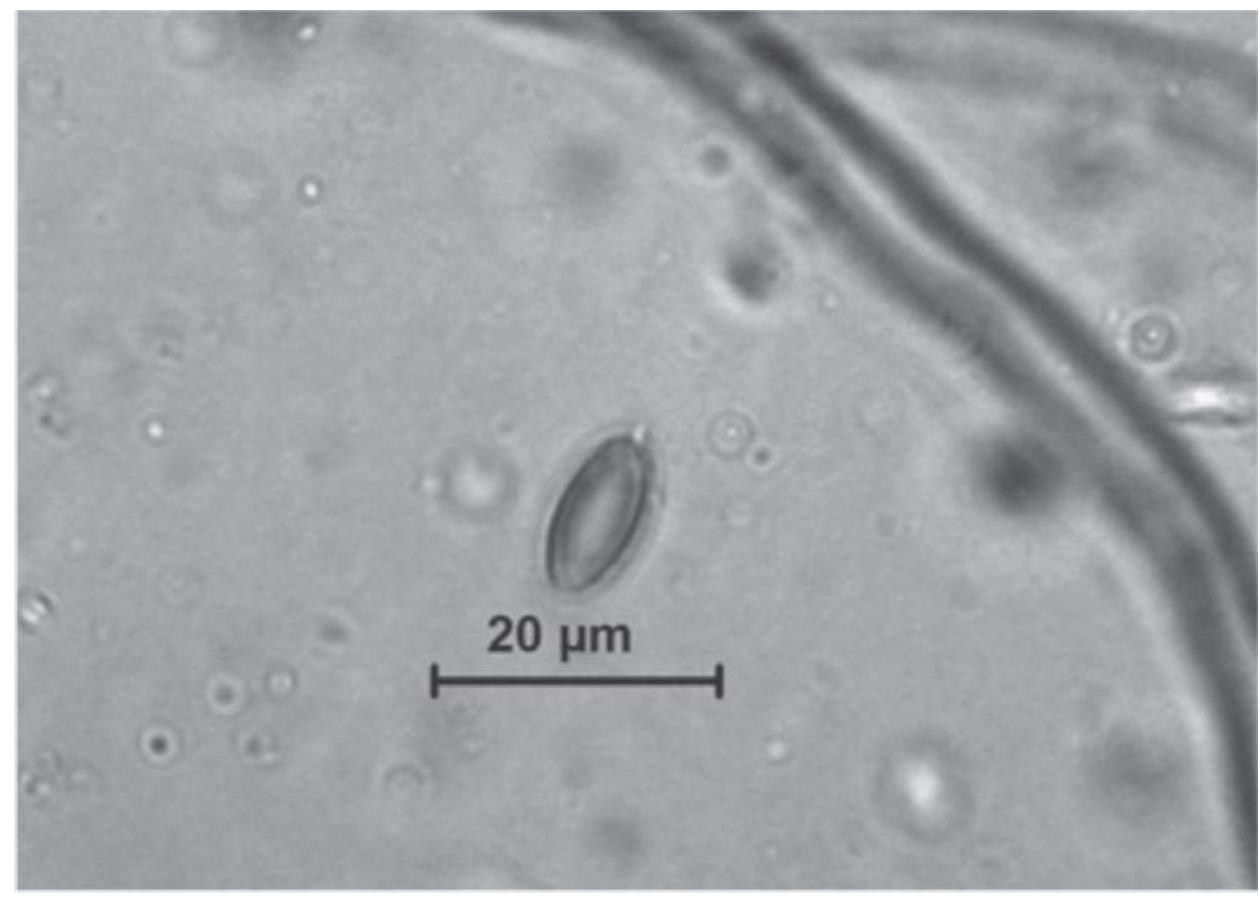

Fig. 16 : Navisporus floccossus on Dalbergia latifolia: boat shaped basidiospore (TF4065)

from Democratic Republic of the Congo ${ }^{13}$. N. minutus was reported on dead hardwood log from Camerron ${ }^{14}$. N. floccosus was reported from Africa, Mexico, Cuba, South America and Darjeeling, West Bengal ${ }^{11}$. Navisporus ortizii was reported on trunk of Licaria jamaicensis from Cuba $^{1}$. N. perennis was reported on hardwood log from Venezuela ${ }^{15}$. $N$. reflexs on dead hardwood log from Central African Republic ${ }^{14}$. N. sulcatus was reported on dead wood from Brazil, South America; French Antilles and United States and $N$. terrestris on soil near Caesalpinia echinata from Brazil?.

From India, Navisporus floccosus was reported on different hosts including Aegle marmelos, Artocarpus integrifolia, Casuarina equisetifolia, Dalbergia sissoo, Ficus religiosa, F. bengalensis, Mimusops elengi, Saraca indica, Shorea robusta, Tamarindus indica and Terminalia arjuna, from West Bengal $2,4,5$; on Ficus bengalensis from Kondagoan and Balod, Chhattisgarh and on Pongamia pinnata ${ }^{17}$. A similar fungus, Amauroderma niger causing root-rot disease in Dalbergia sissoo was reported from Dehradun ${ }^{8}$. N. floccosus causing heart rot in living trees of Ailanthus excelsa was reported along with cultural characters of fungus. The fungus decayed mostly heartwood of living tree by colonizing the central portion of trees ultimately lead to death of trees. Fruiting bodies of the fungus was produced outside the trunk after falling of affected trees ${ }^{9}$.

\section{Conclusion}

Distribution of Navisporus floccosus, a macro-fungus, causing heart rot in tropical trees (Dalbergia sissoo, D. latifolia, Ficus bengalensis, Pongamia pinnata and Shorea robusta) in Chhattisgarh, Madhya Pradesh and Odisha is given alongwith worldwide distribution of eight species of the genus, Navisporus. 
TABLE-2 : World-wide distribution of known species of Navisporus from world

\begin{tabular}{|c|c|c|c|c|}
\hline SN & Name of fungus & Habitat & Distribution & Reference \\
\hline 1. & $\begin{array}{l}\text { Navisporus africanus } \\
\text { Ryvarden }\end{array}$ & $\begin{array}{l}\text { On dead } \\
\text { hardwoods }\end{array}$ & $\begin{array}{l}\text { Democratic Republic } \\
\text { of the Congo }\end{array}$ & Ryvarden (2000) \\
\hline 2. & $\begin{array}{l}\text { Navisporus floccosus } \\
\text { (Bres.) Ryvarden } \\
=\text { Trametes floccosa } \\
\text { Bres. }\end{array}$ & Dead wood & $\begin{array}{l}\text { Africa, Mexico; } \\
\text { Cuba; South } \\
\text { America andIndia } \\
\text { (Darjeeling, Calcutta, } \\
\text { West Bengal, } \\
\text { Andhra Pradesh } \\
\text { and central India) }\end{array}$ & $\begin{array}{l}\text { Prasher and Lalita } \\
\text { (2015);De (1996, } \\
\text { 2006); Nagadesi } \\
\text { and Arya (2013) } \\
\text { This article }\end{array}$ \\
\hline 3. & $\begin{array}{l}\text { Navisporus minutus } \\
\text { Ryvarden }\end{array}$ & $\begin{array}{l}\text { On dead } \\
\text { hardwood log }\end{array}$ & Cameroon & Ryvarden (2018) \\
\hline 4. & $\begin{array}{l}\text { Navisporus ortizii } \\
\text { S. Herrera \& } \\
\text { Bondartseva }\end{array}$ & $\begin{array}{l}\text { On trunk of } \\
\text { Licaria } \\
\text { jamaicensis }\end{array}$ & Cuba & $\begin{array}{l}\text { Bondartseva, and } \\
\text { Errera (1989) }\end{array}$ \\
\hline 5. & $\begin{array}{l}\text { Navisporus perennis } \\
\text { Ryvarden \& Iturr. }\end{array}$ & $\begin{array}{l}\text { On hardwood } \\
\text { log }\end{array}$ & Venezuela & $\begin{array}{l}\text { Ryvarden and } \\
\text { Iturriaga (2003) }\end{array}$ \\
\hline 6. & $\begin{array}{l}\text { Navisporus reflexus } \\
\text { Ryvarden }\end{array}$ & $\begin{array}{l}\text { On dead } \\
\text { hardwood log }\end{array}$ & $\begin{array}{l}\text { Central African } \\
\text { Republic }\end{array}$ & Ryvarden (2018) \\
\hline 7. & $\begin{array}{l}\text { Navisporus sulcatus } \\
\text { (Lloyd) Ryvarden } \\
=\text { Trametes sulcata Lloyd }\end{array}$ & On dead wood & $\begin{array}{l}\text { Brazil, South } \\
\text { America; French } \\
\text { Antilles; United States }\end{array}$ & Lloyd (1983) \\
\hline 8. & $\begin{array}{l}\text { Navisporus terrestris } \\
\text { Gibertoni \& Ryvarden }\end{array}$ & $\begin{array}{l}\text { On soil near } \\
\text { Caesalpinia } \\
\text { echinata }\end{array}$ & $\begin{array}{l}\text { Rio Grande } \\
\text { do Norte, Brazil }\end{array}$ & $\begin{array}{l}\text { Gibertoni et al. } \\
(2004)\end{array}$ \\
\hline
\end{tabular}

\section{References}

1. Bondartseva MA, Errera S. Rod Navisporus Ryv. na Kube. Mikol. Fitopatol. 1989; 23(3): 193-197.

2. Bose SR. Polyporaceae of Bengal X. Journal of Department of Science Calcutta University. 1934; 11: 1-18.

3. Bresadola G. Alcuni funghi della Somalia e della Colonia Eritrea. Annuario del Reale Istituto Botanico Roma (in Italian). 1896; 6: 177.

4. De AB. Fungal flora of Burdwan District, West Bengal, India. I. Journal of Mycopatholical Research. 1996; 34(2): 125-134.

5. De AB. Navisporus floccosus (Bres.) Ryv. - a serious butt rot fungus in the tropical forests of India. Journal of Burdwan Raj College. 2006; 1(1): 9-19. 


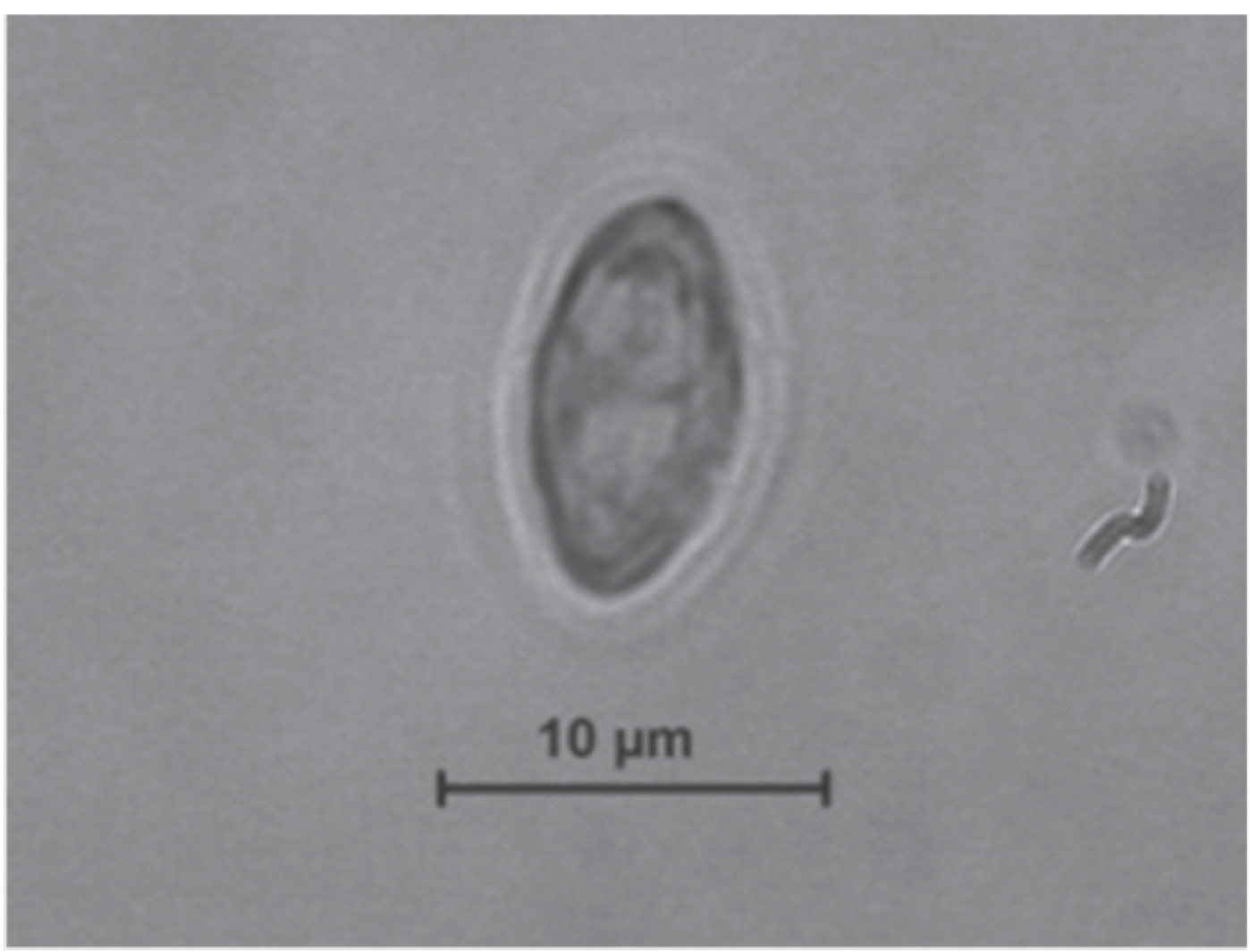

Fig. 17 Navisporus floccossus on Dalbergia sissoo: boat shaped basidiospore (TF4063)

6. Drechsler-Santos ER, Vasconcellos-Neto JRT, Gibertoni TB, Góes-Neto A, Cavalcanti MA Q. Notes on Navisporus: N. terrestris and N. floccosus from Brazil. Mycotaxon. 2007; 101: 265-269.

7. Gibertoni TB, Ryvarden L, Cavalcanti MAQ. Studies in Neotropical polypores 18. New species from Brazil. Syn. Fung. 2004; 18: 44-56.

8. Harsh NSK, Chandra Suresh, Pandey Amit. Amauroderma niger - a new root-rot pathogen of Dalbergia sissoo from India. Indian Forester. 2004; 130(9): 1019-1023.

9. Nagadesi PK, Arya A. A new heart rot disease in Ailanthus excelsa Roxb. caused by Navisporus floccosus (Bres.) Ryvarden. International Letters of Natural Sciences. 2013; 6:1-7.

10. Nagadesi PK, Bhavani J, Arya A. New records of lignicolous fungi from Krishna District, Andhra Pradesh, India. International Letters of Natural Sciences. 2014; 12(1): 55-69.

11. Prasher IB, Lalita. Wood-rotting non-gilled Agaricomycetes of Himalayas. Fungal Diversity Research Series. Springer Netherlands. 2015; p 653.

12. Ryvarden L. The genus Navisporus. Nordic Journal of Botany. 1983; 3(3): 411-413.

13. Ryvarden L. A critical checklist of African polypores. In Associazione Micologica Bresadola (eds), Micologia 2000 471-483+ incl. colour plates Trento: Associazione Micologica Bresadola.

14. Ryvarden L. Studies in African Aphyllophorales 25. New poroid species from East and Central Africa. Synopsis Fungorum. 2018; 38:25-32.

15. Ryvarden L, Iturriaga T. Studies in neotropical polypores 10. New polypores from Venezuela. Mycologia. 95(6):10661077

16. Ryvarden L, Johansen I. A Preliminary Polypore Flora of East Africa. Oslo, Norway: Fungiflora. 1980; p. 443.

17. Tiwari CK, Parihar J, Verma RK and Prakasham U. Atlas of wood decay fungi of central India. Published by Tropical Forest Research Institute, Jabalpur, MP. 2013; p 166. 